\title{
COMMENT
}

Received 24 Apr 2017 | Accepted 1 Jun 2017 | Published 4 Jul 2017

\section{What can we learn from Occupy's failure?}

John Ehrenberg ${ }^{1}$

ABSTRACT Occupy Wall Street was the first mass movement in many years to raise the issue of economic equality and political corruption. It spread rapidly through hundreds of American communities and changed the terms of political life. The reasons for its initial success, and for its ultimate failure, are profoundly important for political affairs and for the American left. Its initial success was a direct result of the silence of the nation's voluntary organizations, political leaders and press in focusing attention on the stagnation of incomes and accompanying upward distribution of wealth that have permanently shaped American society for a generation. The incapacity or unwillingness of the political class, the press and "civil society" to raise this issue in a general and comprehensive fashion left the door open for a vigorous social movement to take the lead. Occupy Wall Street was that movement. But its ultimate failure was a function of its initial strength. Drawing power from a utopian and anarchistic impulse, OWS refused to engage with the established political system. Fearful of being coopted and of engaging with power, its leaders articulated three guiding principles that made it impossible for the movement to follow through on its original positions. Horizontalism, abstention from politics and prefiguration were decidedly antipolitical positions that were rooted in a moral stance and refused to engage with the established institutions of practical life. Having raised the issues of inequality and corruption in a particularly urgent and compelling fashion, OWS deliberately refused to do something about them. In the end, this refusal made common cause with the same forces that it had been denouncing. The Civil Rights, antiwar and women's movements all understood the importance of addressing society as a whole and proposing comprehensive critiques that could mobilize large numbers of people. Their leaders knew how important political institutions and state power were, and their movement's successes resulted from their willingness to act politically. OWS's ultimate failure is an object lesson in how important it is to take positions, engage in debate, and fight for change. There is no substitute for organization, discipline, and authority in public life. Like it or not, existing institutions provide the only context for meaningful public action.

\footnotetext{
${ }^{1}$ Long Island University, Brooklyn, New York, USA Correspondence: (e-mail: john.ehrenberg@liu.edu)
} 
D onald Trump's young presidency has unleashed a wave of protests and demonstrations that reminds many observers of the activism and social movements that came to define "the sixties". Deliberately provocative in his campaign as well as in office, Trump has managed to alienate, offend and irritate significant sections of the population while simultaneously appealing to others. A candidacy organized around jingoism, militarism, sexism and racism has produced a broad pushback that is grounded in time-tested experiences of American democracy and the language of social science.

Theories of "civil society" locate the seedbed of democratic politics in a uniquely American environment of voluntary associations and intermediate organizations that lie between the individual and the state. Alexis de Tocqueville took note of Americans' propensity to organize when he came to this country for a short visit and published Democracy in America in 1835. He noted a remarkably open and fluid society in the New World and tried to explain to his French audience how American individualism and acquisitiveness could be turned to the service of a moderate democracy that would reconcile plebeian strivings for equality with bourgeois property and hierarchy. A preference for voluntary local activity would temper the levelling impulses of the modern state and resist the egalitarianism that had brought the French Revolution to a close with Bonapartist centralization.

Tocqueville's admiration for civil society became fused with Madisonian state-building in the years after World War II. A consensus soon developed among social scientists that too much political engagement had produced both Soviet communism and German Nazism. From David Truman's The Governmental Process (1951) to Almond and Verba's The Civic Culture (1965), pluralist social science was unanimous about how "mass politics" could be a dangerous threat to democratic stability and civil liberties. A retreat from the big questions of justice, state, equality and the like signaled a new embrace of localism and voluntarism that made Tocqueville popular again. Pluralism became the language of a moderate Americanism that married gradual change to stability and institutions. Mass politics and political engagement were replaced by pluralism and periodic elections. Hannah Arendt (1958) and Peter Bachrach (1967) examined the foundations of "totalitarianism" and "democratic elitism" from different vantage points, but they agreed that the American future would be that of a consumer society guided by experts and structured by flexible, pragmatic institutions.

This happy celebration of continuity and gradualism could not survive the great upsurge of the Civil Rights Movement and the associated activities of the Sixties. As it became clear that leaders were often incompetent or worse, that institutions often served the powerful, and that complacency often abetted criminality, Tocqueville's celebration of the local and the small were replaced by mass political action aiming at changes in state policy. The leadership of the Civil Rights Movement knew that Jim Crow could not be broken without support from Washington, the antiwar movement focused attention on Congress and the President, and the women's movement demanded comprehensive solutions to inequality and discrimination. Under pressure from the outside, even mainstream proposals for reform reasserted the importance of the general and comprehensive orientation that only politics could provide; after all, Johnson's Great Society programs relied on state intervention in areas once deemed the province of local authorities.

The conservative counterrevolution that crested with Reagan's election rode to power on a wave of antistatist rhetoric that looked backward to a comfortable, contented period when apathy, disengagement, privacy and consumerism defined the "American way of life". Broad political movements were marginalized as the market came to be the judge of all matters public and private. Despite the fact that Reagan's triumph was made possible by the aggressive use of political power, economics and the market came to be the seat of self-determination and personal freedom while politics and the state were equated with inefficiency, bureaucratic meddling, and the unprincipled schemes of "special interests." The collapse of the Soviet Union seemed to validate the right's warnings about the dangers of centralized political power.

The first President Bush located democratic authenticity in the local activity of "a thousand points of light", an orientation that became bipartisan when his successor declared that "the era of big government is over". Bill Clinton's retreat from the broad politics of state regulation, intervention and redistribution that had marked Keynesian economic policy was of a piece with longstanding Republican attacks on the welfare state. As the rhetoric of "self-reliance" replaced the commitment to social justice, political language began to conform to material reality. Historic levels of inequality supplanted the relative egalitarianism of the "great compression" that had marked the postwar years, and public embrace of civil society mirrored breathtaking levels of private acquisitiveness, debt and consumerism. The long retreat from the New Deal was well under way by the time the United States became the most unequal society in the industrialized world.

The massive upward distribution of wealth and income had been actively encouraged and organized by political authorities for more than thirty years when Occupy Wall Street burst upon the scene in September 2011. Inspired by powerful anti-austerity and anti-globalization efforts in several countries, OWS raise the issue of economic inequality in a particularly compelling way. This is the major reason it spread so rapidly; within 3 weeks, protests were ongoing in over 95 cities across 82 countries and in over 600 American communities. It was as if an entire generation had decided to wake up and take to the streets at the same time. Resignation and apathy gave way to anger and commitment as "civil society" reasserted itself with a vengeance. The clear threat that inequality posed to American democracy was now on everyone's lips. The suffocating silence that had masked economic inequality and political corruption was shattered, the Tea Party was kicked off the front pages, people started talking about social justice in entirely new ways, and millions of young people suddenly took heart. Politicians, newspapers, religious leaders and almost every institution in the country were compelled to address the issue that they had studiously ignored for decades.

But it was not long before the realities of politics and power had to be confronted, and here is where OWS proved unequal to the task it had set itself. David Graeber, one of the movement's early leaders, skillfully summarized the thoughts of many of the movement's young participants and his searing indictment of politics as usual touched nerves around the entire country. But it also contained the seeds of the movement's ultimate failure.

Graeber articulated three interrelated positions that became central to OWS's stance. Inspired by the classical anarchist rejection of political engagement and resting on a moral stance, they proved wildly attractive at first but soon degenerated into empty posing and indignant rejection of "the system". Direct democracy, "horizontalism" and an insistence on consensus summarized the indictment of existing political habits. A refusal to recognize the legitimacy of established institutions expressed the movement's refusal to engage in the dirty business of political programs and the exercise of power. Finally, a claim that the movement's structure had to "prefigure" the world to which it was committed solidified the utopian element that is present in many protest movements (Graeber, 2013).

A rejection of hierarchy, decision-making and majority rule meant that discourse replaced politics, an obsessive concern with 
process replaced a concrete engagement with power, and the demand for unanimity meant that nothing would ever get done. Everyone should have a right to speak about everything, no one should be bound by any position with which one was in disagreement, and majority rule was discarded in favor of a consensus that almost never materialized. Elaborate rituals accompanied endless meetings and hours of talk. OWS's rejection of political corruption and its exposure of decision-makers' complicity in decades of inequality and injustice morphed into a rejection of established institutions and a refusal to engage in politics of any sort. Principles were never articulated, demands were never formulated, and allies were never sought in any serious way. The claim that process was the same as content led OWS to claim that "prefiguring" could substitute a moral pose for the dirty business of engaging with power, thinking politically, taking positions, making demands and-if necessary-compromising. A refusal to make demands became all the more mystifying as allies began to wonder if posing was substituting for making decisions, formulating goals and developing tactics. Not many people knew what Occupy Wall Street wanted, but a lot of people knew how it worked.

The problem is that process is not the same as politics, and OWS often acted as if it really believed that the future could be created by proclamation. Long after it became clear that "structurelessness" often created the conditions for hierarchy and that effective action requires authority and decision, OWS continued to pretend that putting forth noble ideas could substitute for the hard, prosaic work of organizing. Structurelessness and egalitarianism do not translate automatically into moral authority or broad acceptance. Making decisions, taking positions and engaging in sustained action do not have to mean oppression and dictatorship. There are ways to combine the strength of local initiative and authoritative leadership. Movements that make a difference find them (Freeman, 1970).

Occupy Wall Street was convinced that the only way to confront a game whose rules are stacked was to reject the system tout court and work to create alternative institutions. Only a radical withdrawal could redeem a world deeply injured by economic inequality and political corruption. Autonomous action from below was the only authentic form of protest and would eliminate the possibility of being "coopted", an obsessive fear of the Occupiers.

This terror of cooptation fed a rejection of institutional politics altogether. Compromise was out of the question, engaging with existing institutions was a trap, and searching for allies was a fool's errand. No good would come from any attempt to reform a system that was beyond repair.

The terrible thing about all this is that Occupy was really on to something important. It was the first mass movement to raise the issue of economic inequality in many years, and it did so in a particularly compelling fashion. People who had despaired of any counter to American plutocracy welcomed its appearance and hoped that it would lead to an engaged movement for systemic change. Occupy was right in its central claim that inequality was polluting American society root and branch. The problem was that it did not do much about it beyond talking about it.

The talk was certainly important, and OWS played a central role in putting economic inequality at the center of contemporary political discourse. But its talk did not amount to the revolutionary transformation that Occupy claimed to embody. A great opportunity was lost because OWS refused to recognize that the political institutions of a democratic state give movements the opportunity to protest against the conditions that call them into being. The consequent abstention from politics prevented an indignant, righteous cry of protest from developing into an engaged, effective democratic political movement.
There is no escaping from political engagement because there is no escape from power and authority in modern life. Renouncing political activity in the name of ideological purity can have no other effect than to drive people back into the arms of the status quo. A fundamental conceptual error lay at the heart of OWS's mistake. It was right that the obscene level of American inequality was the result of years of conscious state activity combined with the normal actions of capitalist markets. Occupy Wall Street did raise important issues about equity and democracy in a direct, urgent and confrontational manner that resonated powerfully with millions of people. But more was required. It failed to recognize that the political system that had helped produce the problem in the first place was also the path to a resolution. In a radical reversal of its transformative potential, its antistatism led Occupy into a de facto alliance with the same elements that have been systematically dismantling American democracy for a generation. The one percent against whom it ranged itself are always probing to weaken the welfare state, hollow out its public functions, and paralyze its capacity to provide for the common good. In its unwitting way, OWS never really challenged this most basic feature of the past 35 years (Zucker, 2015).

A commitment to direct democracy, a rejection of institutional engagement, and a love of "prefiguration" are no substitutes for effective action. More is required, and that more was beyond OWS's capacities. This was the real tragedy, for Occupy was really on to something important. It crystallized a level of resistance that had been silently building for years, and when it broke out it changed the way people thought about inequality. It thrust fundamental questions of justice and equity onto the front burner of American politics, it mobilized many thousands of people to take to the streets, it dominated media coverage for a time, it forced people to confront what had been developing for an entire generation, and it had a dramatic effect on the way people thought about economics and politics. "We are the 99 percent" was a wonderful rallying cry, a protest against the concentration of wealth and a reminder that what had been done could be undone. But the sorts of changes that Occupy demanded cannot be accomplished by serving as a moral example, refusing to have leaders and renouncing political activity. No one knew that better than the leaders of the most effective democratic mass movement in recent American history.

The Civil Rights Movement understood the importance of seizing and holding the moral high ground, but that understanding was part of the political and strategic thinking that Occupy rejected in principle. Its bold proclamations of revolutionary changes notwithstanding, the sorts of things that Occupy demanded require the application of force and coercion. The "one percent" cannot be expected to give up their wealth and power just because the self-appointed spokespeople for the "ninety-nine percent" think they should. Moral indignation is a crucial element of successful movements but must be reinforced by the application of power and the capacity to get things done. And power implies compulsion and force. No one knew that better than Doctor King. From the very beginning of the Montgomery Bus Boycott until the Civil Rights Act and Voting Rights Act of 1964 and 1965, it was clear to anyone who cared to look that Jim Crow could not be broken without the sustained support of the national government.

For all of its very real failings, Occupy Wall Street was right about the important thing. Deepening inequality and gigantic concentrations of private power constitute a dangerous threat to democracy. It was right that political, economic and social affairs are as mutually dependent today as they have always been. It was right that extending democracy to the economy, the state and civil society is the central challenge of contemporary life. Its 
failure to understand that this requires comprehensive political activity and an integrated ideology was its most important obstacle to developing a sustained movement for political, social and economic democracy. But all is not lost. There is a lot of evidence that this lesson has been learned from Occupy's shortterm failure. Donald Trump has already provided plenty of opportunities for broad political activity that's oriented to the national community and to the political institutions that comprise the modern state. From the Women's March and the March for Science to hundreds of local demonstrations, sit-ins, town halls and marches, "the resistance" seems to have learned the lesson. High-minded appeals and moral exhortations are not going to reverse thirty years of relentless assaults on social justice. Placards and signs might hopefully declare that "love trumps hate," but that's just not true. "Love" won't trump hate. Political power will (Ehrenberg, 2017).

None of this is new. Plato thought that the "philosopher-king" would fuse knowledge and power, Aristotle developed the first systematic theory of comparative politics, Machiavelli insisted that "virtue" required political engagement, Locke and Hobbes claimed that civil society is constituted by state power, and Rousseau taught that only active citizenship could elevate mankind from childhood to moral maturity. More than two thousand years of political, social and economic theory have recognized how important it is to seek power and use it wisely. In one of those strange moments that can transform weakness into strength and failure into success, there is reason to hope that the near future will be more productive than Occupy. Democracy depends on it.

\section{References}

Almond G and Sidney V (1965) The Civic Culture. Little, Brown: Boston, MA. Arendt H (1958) The Human Condition. University of Chicago Press: Chicago, IL. Bachrach P (1967) The Theory of Democratic Elitism. Little, Brown: Boston, MA. Ehrenberg J (2017) Civil Society: The Critical History of an Idea. New York University Press: New York.

Freeman J (1970) The Tyranny of Structurelessness, http://www.jofreeman.com/ joreen/tyranny.htm.

Graeber D (2013) The Democracy Project: A History, A Crisis, A Movement. Spiegel \& Gran: New York.

Truman D (1951) The Governmental Process. Knopf: New York.

Zucker G (2015) "Occupy wall street and the challenge of the 'new'. Logos; 14 (1).

\section{Additional information}

Competing interests: The author declares that there are no competing interests.

Reprints and permission information is available at http://www.palgrave-journals.com/ pal/authors/rights_and_permissions.html

How to cite this article: Ehrenberg J (2017) What can we learn from Occupy's failure? Palgrave Communications. 3:17062 doi: 10.1057/palcomms.2017.62.

Publisher's note: Springer Nature remains neutral with regard to jurisdictional claims in published maps and institutional affiliations.

(c) (i) This work is licensed under a Creative Commons Attribution 4.0 International License. The images or other third party material in this article are included in the article's Creative Commons license, unless indicated otherwise in the credit line; if the material is not included under the Creative Commons license, users will need to obtain permission from the license holder to reproduce the material To view a copy of this license, visit http://creativecommons.org/licenses/by/4.0/

C) The Author(s) 2017 